\title{
青色蛍光誘蛾灯に飛来した昆虫と茶害虫の種類
}

農林水産省茶業試験場

刑 部 勝

\section{The Species of Insects and Tea Insect Pests Caught by a Blueness Fluorescent Light Trap}

\author{
By Masaru OSAKabE \\ National Research Institute of Tea
}

\section{1 まえがき}

当場虫害研究室では 1947 年以降現在までの30余年閒， 茶害虫の年々における発生状況のは握と発生予察の甚礎 資料を得ることをねらいとして，誘䗩灯による茶害虫の 発生状況譋査を続けてきた。得られた結果は必要に灾じ てそのつど個々の害虫の発生状況として情報提供してき たか，誘蛾灯に飛来した茶䈏虫全体についての系統的な 発表はまたなされていない。よって著者はこれらの調査 結果を整理，公表すべく意図し，最初偟全体をは握する 意味で誘蛨灯に飛来した昆虫と茶害虫の種類について整 理した。本報ではその結果について報告する。

\section{2 調 查 方 法}

調査は誘蛾灯飛来した昆虫の種類と茶害虫の種類に ついて行った。このうち誘蛾灯に飛来した昆虫の種類に ついては1951〜1960年に行った誘蛾灯飛来昆虫の全数調 查の結果によって, 誘蛾灯に飛来した茶害虫の種類につ いては1947〜1979年に行った茶害虫の発生状況調查の結

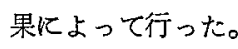

調查に用いた誘蛾灯は $20 \mathrm{~W}$ ，湿式の青色蛍光誘蛾灯で 四 1 亿示した当場内の茶園の一部に常設した。調查期間 は原則として毎年 4 月 1 日〜12月末日までとし，毎日 1 回，午前中に調查した。調查対象虫は1947〜1960 年は茶
害虫を含む誘殺昆虫すべて，1961～1979年は誘殺茶害虫 すべてとし，可能限り分別，記録した。誘蛾灯は誘殺数 が正しくは握されるょうにするため，照度変化防止のた めの定電圧装置の設置, 野鳥による誘殺虫锰盗防止のた めの水盤周囲への防鳥網の設置, 水面落下虫逃亡防止の ための水盤液面への少量注油などを行った。

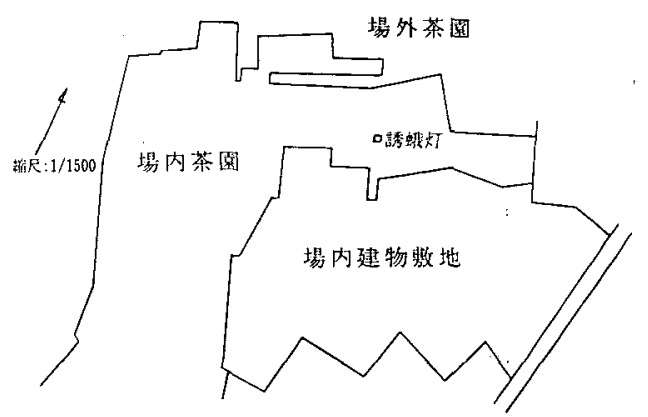

図 1 茶害虫発生状沉調査のための誘蛾灯設置場所

\section{3 調 查 結 果}

\section{1 青色蛍光誘蛾灯に飛来した昆虫の種類}

表 1 亿当場の茶園内に設置された青色蛍光誘㧴灯に飛 来した昆虫の種類数を1951〜1960 年調查の結果で示し た。

表 1 青色蛍光誘蛾灯々飛来した昆虫の種類数（静岡県金谷町，1951～1960年調査）

\begin{tabular}{|c|c|c|c|c|c|c|c|c|c|c|}
\hline & \multirow{2}{*}{ 目 } & & \multicolumn{7}{|c|}{ 科 } & \multirow{2}{*}{ 目別誘殺数比 } \\
\hline & & & \multicolumn{2}{|c|}{ 科 } & \multicolumn{2}{|c|}{ 名 } & \multirow[t]{2}{*}{ 誘 } & 殺 数1 & \multirow{2}{*}{ 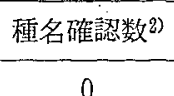 } & \\
\hline \multirow{4}{*}{$r$} & & & t & ע & ₹ & 科 & & 0 & & (\%) \\
\hline & ン & 目 & オ & $=t$ & ע & 科 & & 0 & 1. & \\
\hline & & & r & ข & ボ & 科 & & 57 & 1 & \\
\hline & 計 & & & & & & & 57 & 2 & 0.06 \\
\hline
\end{tabular}




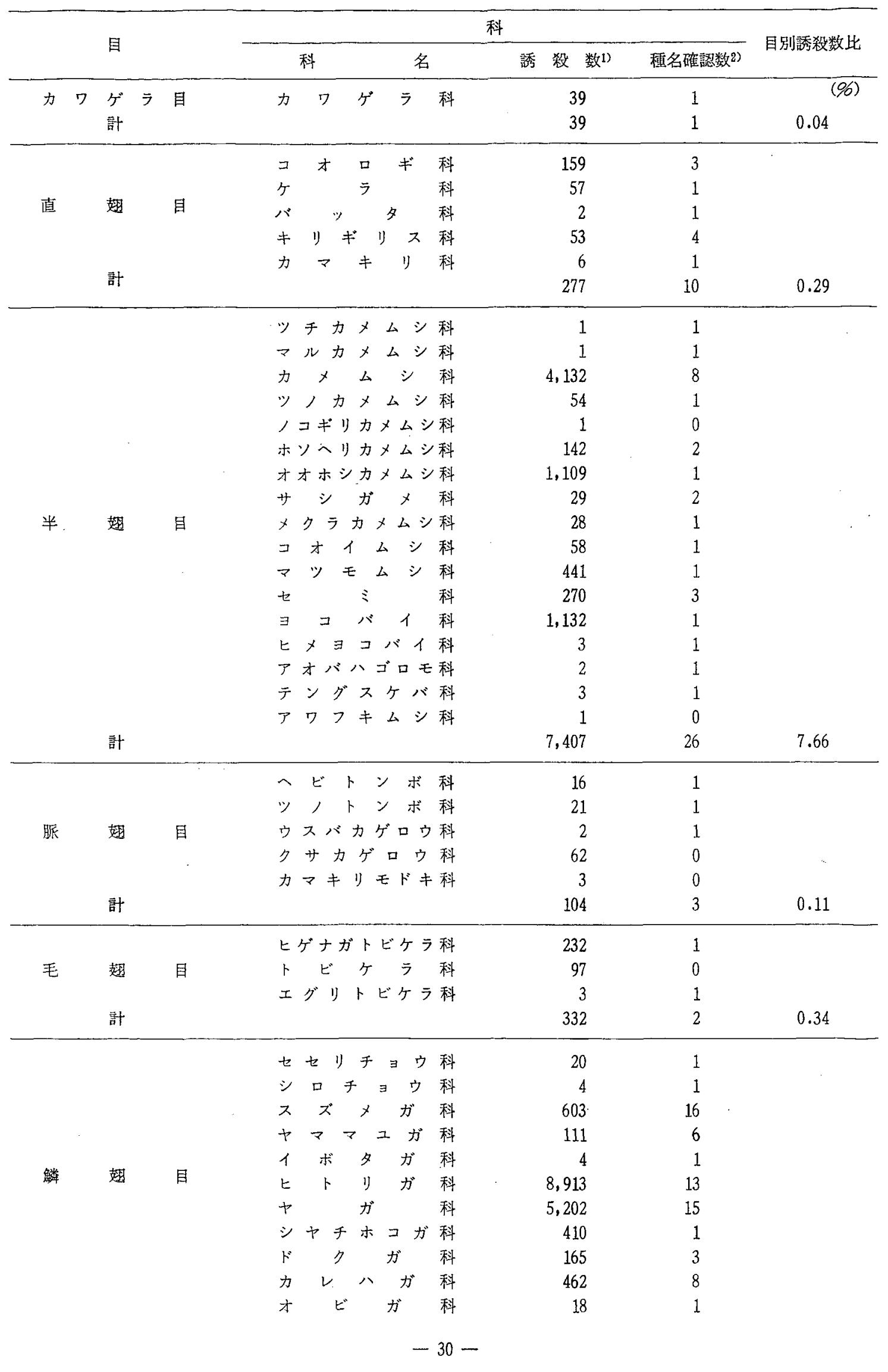




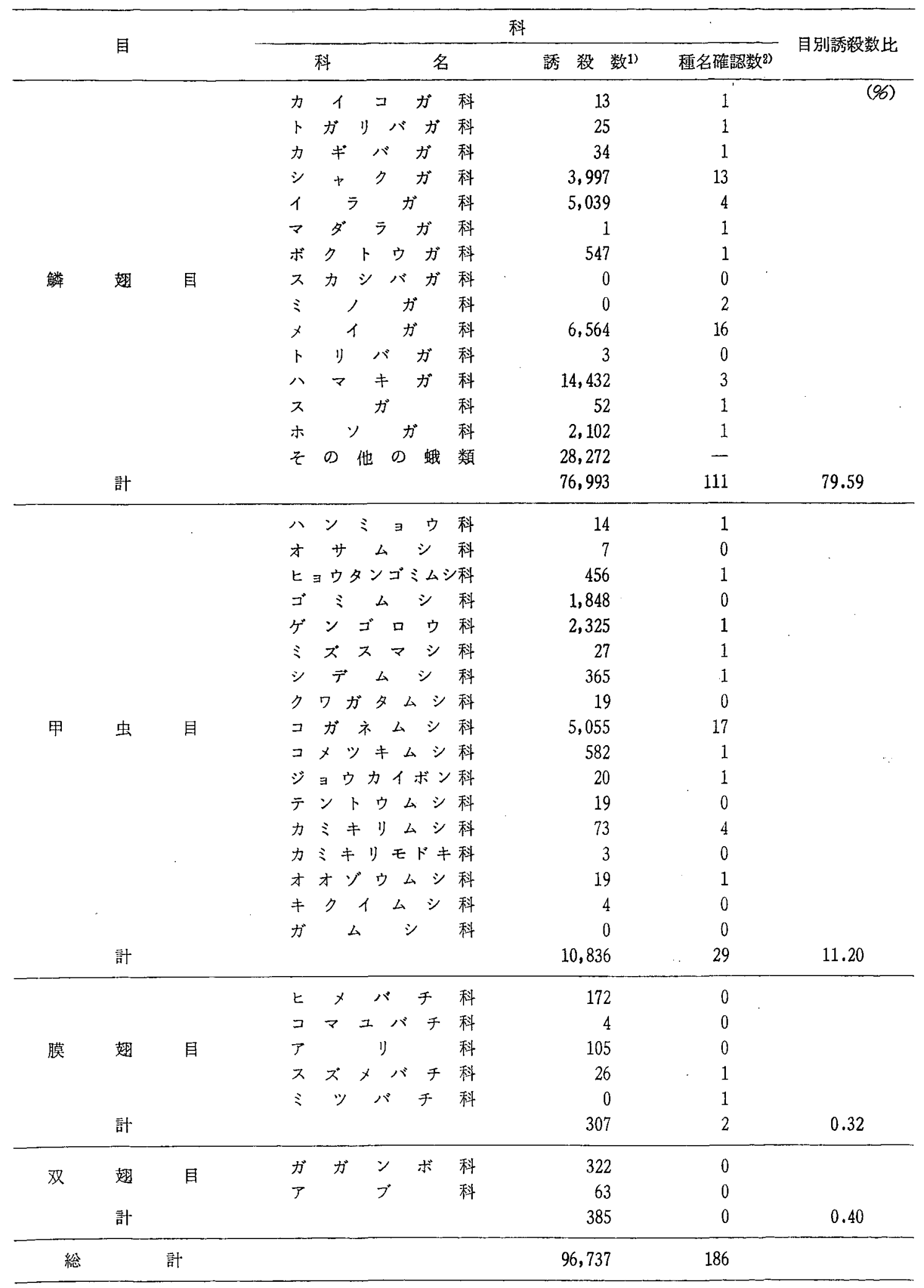

注：1）年平均誘殺数で，欗内の誘殺数 0 は年平均誘殺数が 0 以上 0.5 末満であることを示す。

2）種名確認数は南川仁博, 植田態治による1951 1960年の調查記録から求めた。 
この結果によると, 当場の茶園内に設置された青色蛍 光誘蛾灯に飛来した昆虫類は，判明したものたけではあ るが，10目，83科，186種であった。认ま，この結果か ら種名確認数を目別にみると, トンボ目 2 種, カワゲラ 目 1 種, 直翅目 10 種, 半翅目 26 種, 脈翅目 3 種, トビケ ラ目 2 種, 䚬翅目 111 種, 甲虫目 29 種, 膜翅目 2 種で, 鳞翅目に属するものが圧倒的に多かった。表 2 にこれら の種名をまとめて示す。
次に，表 1 の結果からこれら誘殺昆虫の誘殺数を目科 別にみると，目別では䚬翅目に属する昆虫の誘殺数が王 倒的に多く全体（96,737 頭/年）の約 8 割を占め, 科別 では鱗翅目のハマキが科に属するすのが最多であった。

しかし，表1に示した誘殺昆虫の中には種名がはっき り分からないものが多く，特に鱗翅目の中の蛾類では鱗 翅目全体の約 $2 / 5$ に相当する約 30,000 頭の種名が判別て きなかった。

表 2 当場の茶園内に設置された青色蛍光誘蛾灯に飛来した昆虫類（1951～1960年調查）

\begin{tabular}{|c|c|c|c|c|c|}
\hline \multirow[t]{3}{*}{ r } & \multirow{3}{*}{$\begin{array}{l}\text { z } \\
\text { E }\end{array}$} & Odona & & . & 年平均誘殺数 $\mathrm{f})$ \\
\hline & & $ヤ: ン$ & $\checkmark$ & Anotogaster sieboldii Selys & 0 \\
\hline & & オカラトン & ボ & Orthetrum albistylum speciosum Uhler & 57 \\
\hline \multirow[t]{2}{*}{ カ } & $\eta$ & ゲラ 目 & ptera & & \\
\hline & 力 & $ケ ゙$ & ラ & Kamimuria tibialis Pictet & 39 \\
\hline \multirow[t]{11}{*}{ 直 } & & 趐 目 Orthor & ptera & & \\
\hline & t & $\therefore x \sqsupset$ オ & ギ & Gryllus nipponensis Shiraki & 39 \\
\hline & 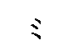 & ッカドコオロ & ギ & Loxoblemmus doenitzi Stein & 0 \\
\hline & 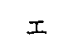 & ン コ オロ & ギ & Teleogryllus emma Ohmachi et Matsuura & 82 \\
\hline & $ヶ$ & & ラ & Gryllotalpa africana Palisot de Beauvois & $5 ?$ \\
\hline & r & ノサマバッ & タ & Locusta migratoria Linné & 2 \\
\hline & $\eta$ & ビ キ リギ & ス & Euconocephalus thunbergi Stål & 45 \\
\hline & $\eta$ & $ッ \quad \square \quad 厶$ & シ & Mecopoda nipponensis de Haan & 0 \\
\hline & ウ & $\nabla \quad$ オ & 1 & Hexacentrus japonicus Karny & 8 \\
\hline & $\eta$ & ダマキモド & $\neq$ & Holochlora japonica Brunner von Wattenwyl & 0 \\
\hline & 力 & キ & リ & Paratenodera angustipennis de Saussure & 6 \\
\hline \multirow[t]{22}{*}{ 半 } & & 目 Hemip & ptera & & \\
\hline & ッ & チ カ メ 厶 & シ & Macroscytus japonensis Scott & 1 \\
\hline & $\eta$ & 口カ メ & シ & Scotinophara lurida Burmeister & 1 \\
\hline & 1 & ネ力メム & シ & Lagynotomus elongatus Dallas & 10 \\
\hline & $\eta$ & サギカ メ & シ & Halyomorpha mista Uhler & 3 \\
\hline & $\boldsymbol{\gamma}$ & オクサカメム & シ & Nezara antennata Scott & 135 \\
\hline & ッ & ヤアオカメム & シ & Glaucias subpunctatus Walker & 2,172 \\
\hline & 1 & チモンジカメム & シ & Piezodorus hybneri Gmelin & 6 \\
\hline & 于 & ヤバネアオカメム & シ & Plautia stali Scott & 1,783 \\
\hline & 了 & オクチブトカメム & シ & Dinorhynchus dybowskyi Jakovlev & 0 \\
\hline & $\exists$ & ッボシカメム & シ & Homalogonia obtusa Walker & 23 \\
\hline & ヒ & メツノカメ厶 & シ & Elasmucha putoni Scott & 54 \\
\hline & $\eta$ & モへリカメ厶 & シ & Leptocorisa chinensis Dallas & 12 \\
\hline & 木 & ソへリカメム & シ & Riptortus clavatus Thunberg & 126 \\
\hline & 七 & メ 木シカメム & シ & Physopelta cincticollis Stal & 1,109 \\
\hline & キ & イロサシガ & $x$ & Sirthenea flavipes Stal & 19 \\
\hline & $\exists$ & コヅナサシガ & 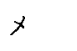 & Agriosphodrus dohrni Signoret & 10 \\
\hline & ウ & スミドリメクラガ & $x$ & Lygocoris spinolai Meyer-Dür & 28 \\
\hline & タ & ガ & $x$ & Lethocerus deyrollei Vuillef roy & 58 \\
\hline & $\checkmark$ & ッ & シ & Notonecta triguttata Motschulsky & 441 \\
\hline & $\boldsymbol{\gamma}$ & ブ ラ ゼ & 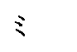 & Graptopsaltria nigrofuscata Motschulsky & 0 \\
\hline & $=$ & $1=1 セ ゙$ & $\Sigma$ & Platypleura kaempferi Fabricius & 268 \\
\hline
\end{tabular}




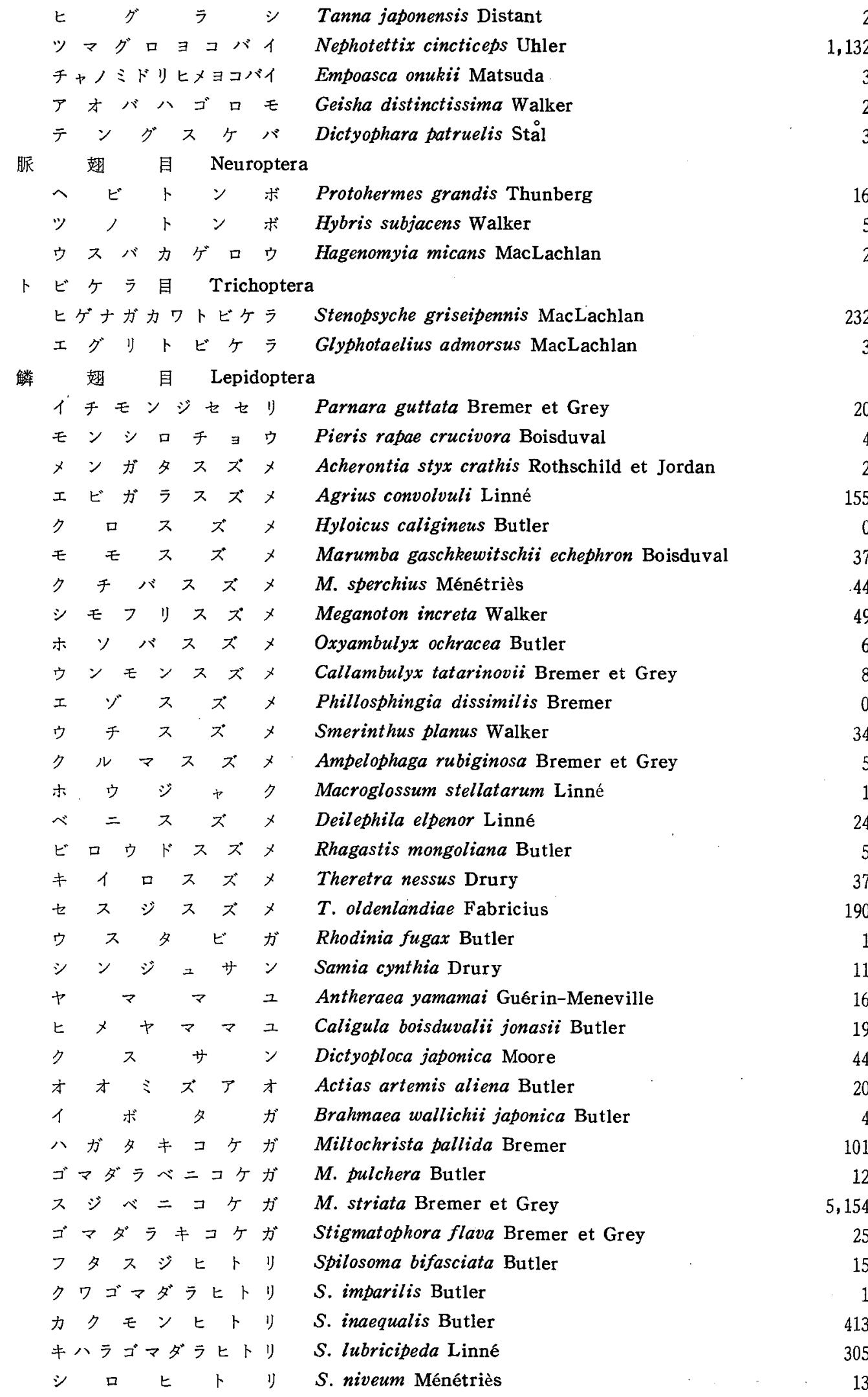




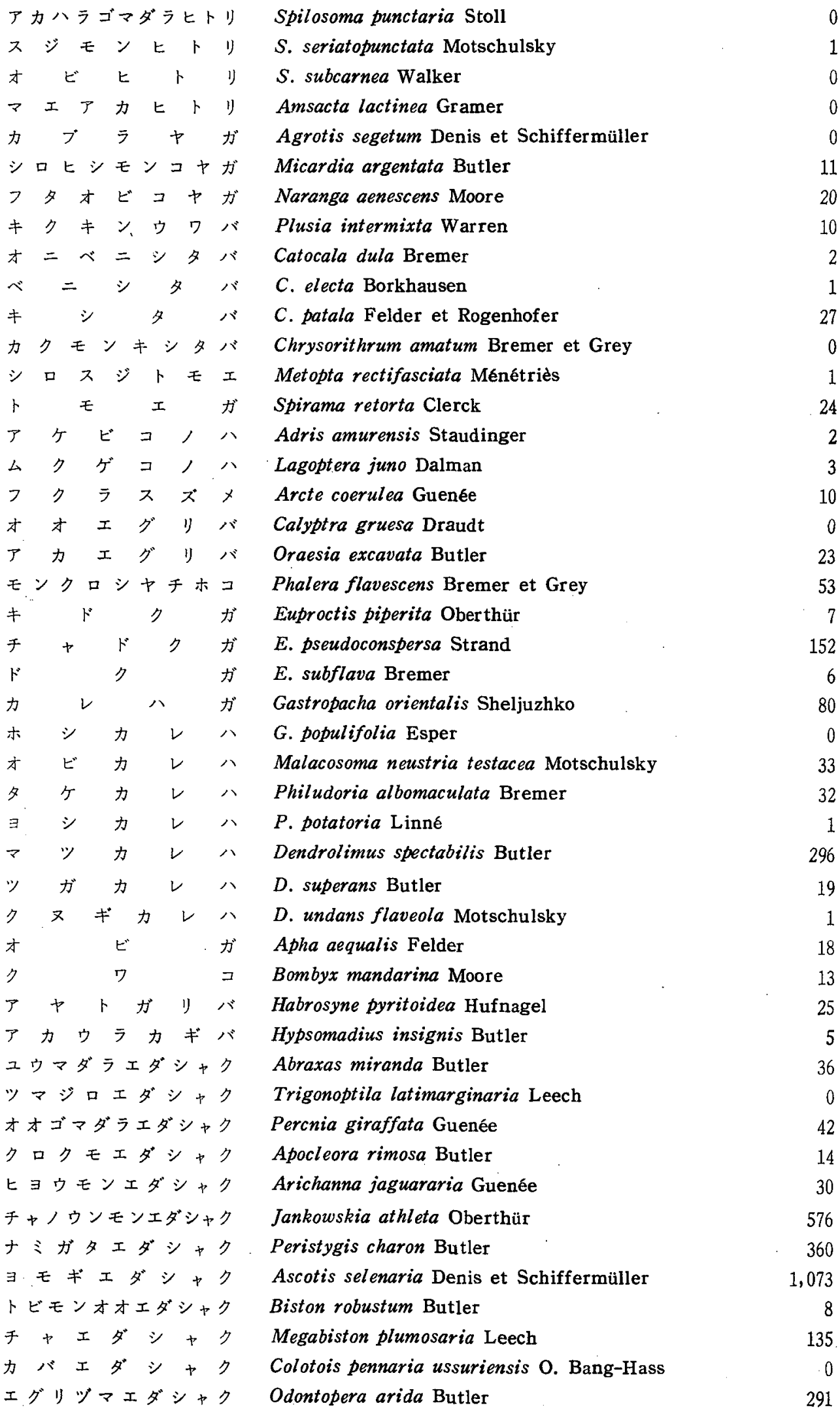




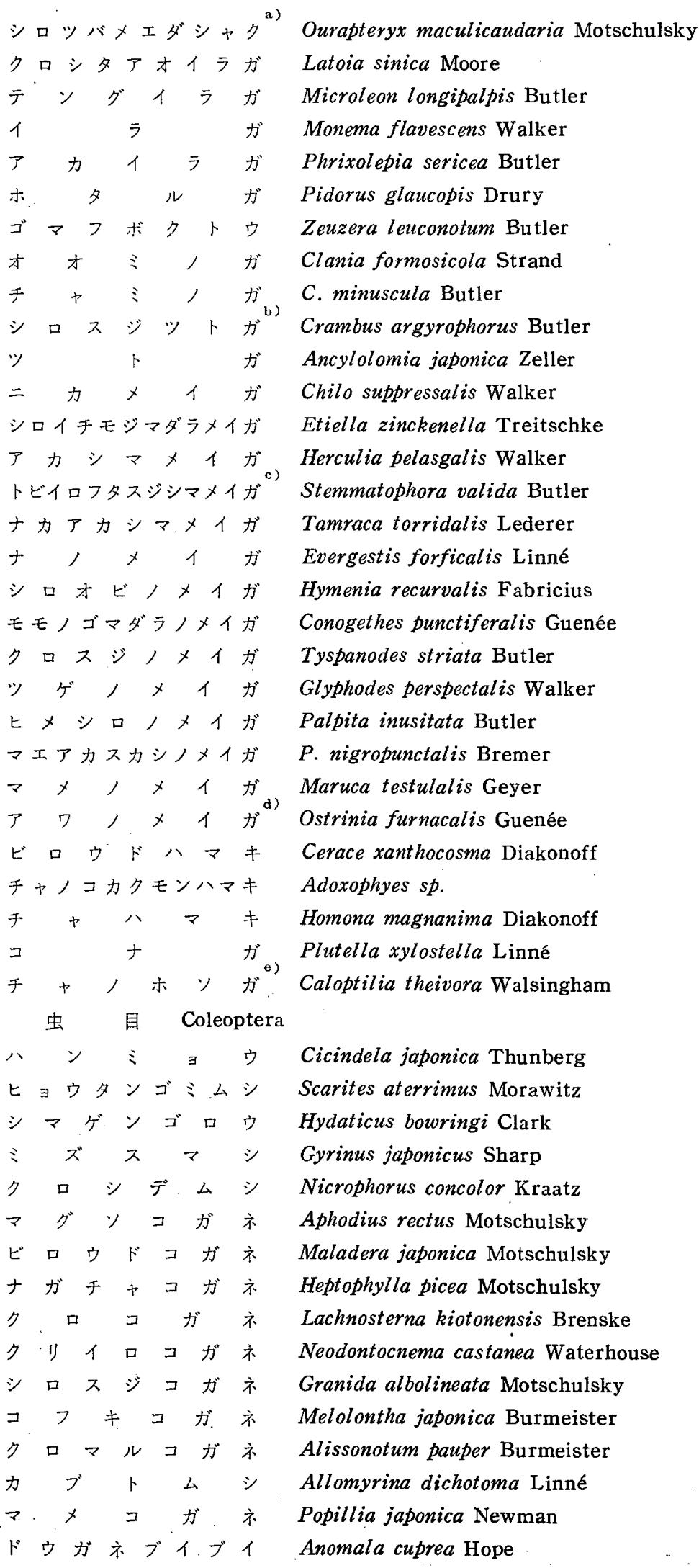

年平均誘殺数 


\begin{tabular}{|c|c|c|c|c|}
\hline 七 & ガ & ネ & Anomala rufocuprea Motschulsky & 1,893 \\
\hline z & $\ddot{z}$ & ネ & A. testaceips Motschulsky & 650 \\
\hline サ & ク コ ガ & ネ & A. daimiana Harold & 109 \\
\hline$セ$ & $マ$ ダラコガ & ネ & A. orientalis Waterhouse & 175 \\
\hline 力 & + & ン & Rhomborrhina japonica Hope & 134 \\
\hline 八 & ナ $\quad$ グ & リ & Eucetonia pilifera Motschulsky & 4 \\
\hline 七 & ゲ コメッ & $\neq$ & Pectocera fortunei Candèze & 14 \\
\hline$\ddot{*}$ & $\exists$ ウ 1 ボ & ע & Athemus suturellus Motschulsky & 20 \\
\hline , & コギリカミキ & リ & Prionus insularis Motschulsky & 34 \\
\hline 七 & ン, カ & リ & Acalolepta luxuriosa Bate & 0 \\
\hline シ & ロスジカミキ & ग & Batocera lineolata Chevrolat & 2 \\
\hline リ & ンゴカ $ミ$ キ & リ & Oberea japonica Thunberg & 5 \\
\hline オ & オ ゾウム & シ & Sipalinus gigas Fabricius & 19 \\
\hline & 目 Hyme & enopt & & \\
\hline$\neq$ & 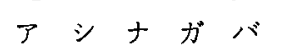 & チ & Polistes jokohamae Radoszkowski & 26 \\
\hline$\Sigma$ & バ & チ & Apis cerana Fabricius & 0 \\
\hline
\end{tabular}

注：a）調查時に本種と形態的に酷似しているウスキッバメエダシャク O. nivea Butler を一部湿記した可能性 がある。

b) 井上はシロスジットガに対して2 種の学名を記载し, 新称のものに対して Pseudocatharylla inclaral is Walker の学名を記しているが，記載によると新称のものはごく限られた地域で少数採集されたたけけであ ると述べているので, ここでは発生地に普遍性があるこの学名を採用した。

c）南川らではニセシロモンシマメイガと記されている。

d) 本種はフキノメイガ O. scapulalis Mutuura et Munroe と形態的に酷似しているので調查時に耐者を 混記した可能性もある。

e)黑子は本種の和名をチャノ八マキホソガと改称しているが，ここでは農林害虫名鑑の和名に従った。

f） 欄内の年平均誘殺数 0 は 0 以上 0.5 未満であることを示す。

\section{2 青色蛍光誘蛾灯に飛来した茶害虫の種類}

表 3 亿当場の茶園内に設置された青色蛍光誘蛾灯に飛 来した茶害虫の種類を1947～1979年調查の結果で示し た。

この結果によると，当場の茶園内に設置された青色蛍 光誘蛾灯に飛来した茶害虫の種類は直翅目のクダマキモ ドキ，半翅目のチャバネアオカメムシ，ウスメドリメク ラガメ，チャノミドリヒメヨコバイ，アオバハゴロモ， 䚬翅目のクワゴマダラヒトリ, カブラヤガ, 八スモンヨ トゥ, チャドクガ, ドクガ, チャノウンモンエダシャク， ナミガタエダシャク，ヨモギエダシャク，トビモンオオ エダシャク，チャエダシャク，エグリッ゙マエダシャク， テングイラガ, イラガ, アカイラガ, ゴマフボクトゥ， オオミノガ, チャミノガ, アカシマメイガ, トビイロフ タスジシマメイガ, ナカアカシマメイガ, ビロウド八マ キ, チャノコカクモン八マキ, チャハマキ, チャノホソ ガ，甲虫目のナガチャコガネ括よびヒメコガネの計 31 種 類であった。

これらの茶害虫の5 らハスモンョトウ Spodoptera litura Fabricius を除くすべてのものは1947〜1960 年 に行った誘蛾灯飛来昆虫の全数調查の中で確認されたも ので，表 2 にも誘蛾灯飛来昆䗰として示してあるが， 八スモンョトウについては1964年にチャの幼苗の茎葉を 加害することが確認されたためにその後の調査で追録さ れたものである。また，ナガチャコガネについては誘蛾 灯飛来昆虫の全数調查を行った 1947年〜1960年の時点で は茶害虫として扱われていなかったが，1974年ころ本程 によるチャの被害が初めて確認され，その後の調査でも その被害が追認されたために茶害虫として追加されたる のである。

青色蛍光誘蛑灯に飛来した昆虫類の中には，このほか に，形態的に酷倾しているためにシロツバメエダシャク と混記された可能性がある茶害虫のウスキツバメエダシ ヤク Ourapteryx nivea Butler, 茶害虫とされている オオアカマエアツバ Simplica niphona Butler の誤記 録かとみられるマエキアッバ (学名不詳) などがあった がともに詳しいことはわからないので，ここでは茶害 虫として扱わないことにした。 
表 3 青色蛍光誘㧴灯に飛来した茶害虫の種類

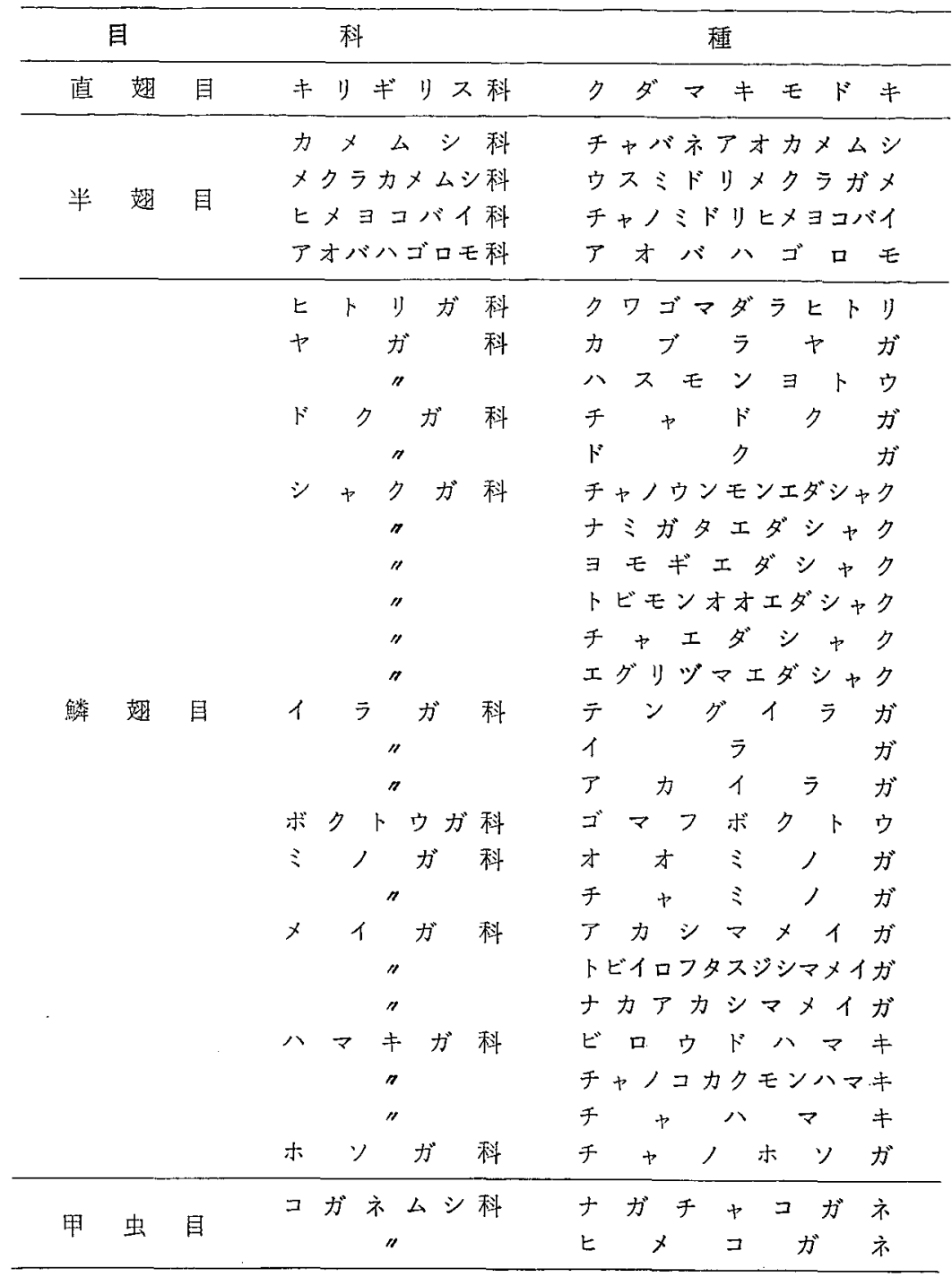

\section{4 考察}

以上，当場の茶園内に設置された青色蛍光誘蛾灯に飛 来した昆虫と茶害虫の種類について1947～1979年調査の 結果で述べた。いまこれらの結果について, 調査期間内 に打ける誘蛾灯周辺㻴境の変化と誘殺状況との関係も含 めて, 誘殺昆虫と誘殺茶害虫の程類とを別々に考察する と次のと扣りである。

\section{1 青色蛍光誘娥灯に飛来した昆虫の種類}

既述表 $1 ， 2$ の結果によると，当場の茶園内に設置さ れた青色蛍光謤蛾灯に飛来した昆虫の種類は 10 目，83科 にわたる186種に及び, 誘殺数は総計で96,737頭/年に達 した。そしてこれらの内訳をみると誘殺昆虫の種類，数 ともに鱗翅目に属するものが王倒的に多かった。このこ とは本調查に用いた青色蛍光誘挠灯（湿式）が䚬翅目昆
虫の誘殺に最も適していた，または，誘哦灯を設置した 周辺環境内では䚬翅目に属する昆虫が他の昆虫に比べて 圧倒的に多かったためのいずれかであることを示してい ると考㝋られる。

しかしこれらの結果は，いずれにしても，当場の茶園 で1951〜1960年の間に調べたものであり，かつ，種名確 認数も全誘殺数の約 $50 \%$ に過ぎないので，例光当時であ ったとしてもこの結果をもって青色蛍光誘蛾灯飞飛来し た昆虫のすべてであるとすることはできない。

また，調查を行った1951〜1970年以後農薬等を含む誘 蛾灯周辺環境に大きな変化が生じているので，誘殺され た種類や数について子現時点で表 $1 ， 2$ と同㥞な結果が 得られるとは考えがたい。例えばスジベニコケガについ てみると，本種は茶害虫を除く誘殺昆虫の中で最多の誘 殺数を記録したものであるが $(5,154$ 頭/年)，1951 1960 
年当時では日中でる茶株上で多数の成虫が発見されたが 現在では活とんど発見されないといった状態である。

次に, 誘殺昆虫の種類をチャ以外の農作物害虫の観点 からみると，食用作物，野菜等の害蚆ら林木，推賞用 作物の害虫に至るむで非常に多吱化わたっている。この 原因惗らく，茶害虫のほが，当時戦後の食糧事情の 関係からチャの鮫間に間作されていた食用作物や野菜な ぞを加害していたすのや場内観賞用として植えられて いた庭園樹等（誘蛾灯までの最短距離は約 $25 \mathrm{~m}$ ) を加㕩 していたすのが誘殺されたためであろう。

\section{2 青色蛍誘蛾灯に飛来した茶害虫の種類}

既述 3. 2 の結果によると当場の茶園内に設置された 青色蛍光誘蛾灯に我来した茶害虫の種類は餼翅目害虫を 中心とする 31 種類であった。そしてこれらの種類数は碓 認された誘蛾灯飛来昆虫類の約 $1 / 6$ 亿相当した。

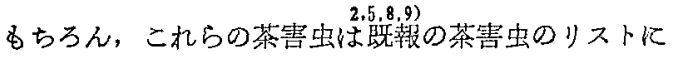
準拠して分別したものであるが，中にはそのまま茶害虫 として扰くには疑わしいるのあある。例克ばチャバ亦 オカメムシ，クワゴマダラヒトリ，カブラヤガなどがそ れである。理由は，これらの寒虫は過去に特殊な条件下 でチャを加害していることが発見されて以降そのまま茶 害虫として記載され続けているが，近年ではその被害が 全く発見されないためである。

このほか，トビイロフタスジシマメイガや近緑他種と 混記された可能性があるナミガタエダシャクについても 疑いがもたれる。特にトビイロフタスジシマメイガにつ いては，南川らがトビイロフタスジシマメイガとアカシ マメイガとは同種であるという見解から両種を合せてト ビイロフタスジシマメイガとし，これをチャの害虫とし て記載しているので(南川ら゙の記載では二セシロモンシ マメイガとなっている)ここではとりあ京ずチャの害虫 として扱うことにしたが，トビイロフタスジシマメイガ とアカシタヌイガとは別種であり, かつ, 過去の茶害虫 のリストトにす記録されていないことから本種をそのまま 茶害虫とするには問題がある。

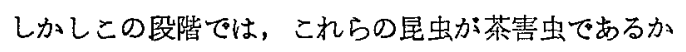
否かを断定する決め手にかける。そのためにここではそ のまま茶害虫として扱らことにするが，この点について は後日改めて詳細に榆討する必要がある。

\section{5 摘 要}

1947 1979年にわたって当場の茶園内に設置された青 色学光誘蛾㓅に飛来した昆虫と茶害虫の種類を調查し た。結果を要約して示すと次のと扣りである。

1） 1951 1960年に調查した結果によると, 訜殺昆虫 数は年平均で約 10 万頭に達したが，これらの昆虫の約 80 \%は䚬翅目に属するすのであった。

2) この調查で種名が確認された昆虫は 186 種であっ
た。しかし，その誘殺数は全誘殺数の約 $1 / 2$ に過ぎなか $\neg \kappa_{0}$

3） 1947〜 1979年の調查で31 種類の茶害蚆誘殺され た。それらの種名はクダマキモドキ，チャバネアオカメ ムシ，ウスミドリメクラガメ，チャノミドリヒメヨコバ 1, アオバ八ゴロモ, クワゴマダラヒトリ，カブラヤ ガ，八スモンヨトウ，チャドクガ，ドクガ，チャ/ウン モンエダシャク，ナミガタエダシャク，ヨモギエダシャ ク，トビモンオオエダシャク，チャエダシャク，エグリ ヅマエダシャク, テングイラガ, イラガ, アカイラガ, ゴマフポクトウ，才オミノガ，千ャミノガ, アカシマメ イガ, トビイロフタスジシマメイガ, ナカアカシマメイ ガ, ビロウド八マキ，チャノコカクモンハマキ，チャハ マキ, チャ/ホソガ, ナガチャコガネ枕よびヒメコガネ である。

この調查は, 当特, 虫害研究室の職員であった南川仁 博, 植田熊治 (1947 1960 年調查), 刑部 勝, 清水靖 子 (1961〜1974年調査) 扎よび刈屋 明, 大苵司誠 （1975１979年調查）の各氏によって行われたものであ る。ここに明記してこれらの方々の労苦に媣甚の謝意を 表する。

\section{6 引用 文 献}

1) 井上寛: 日本産蛾類大四鑑（井上寛俰か共著, 講談社発行), I, 382 (1982).

2) 南川仁博, 刑部 勝: 茶樹の害虫 (日本植物防疫協 会発行), pp. 322 (1979).

3) 阿久津喜作：野菜の病害虫一竞断々防除一（岸 国 平編，全国農村教育協会発行），428～430（1976）。

4) 黒子 浩：日本産蛾類大四鑑（井上 寛活か共著, 講談社発行), I, 179 (1982)。

5) 応動昆監修：農林害虫名鑑（日本植物防疫協会発 行), pp. 307 (1980).

6) 刑部 勝, 小泊重洋：茶技研, No. 66, 15 21 (1984).

7) 小泊重洋, 俋川知広: 茶樹の害虫とその防除（武田 薬品工業(佅発行, 非売品), pp. 172 (1982).

8）神谷一男，松下伝吾：日本産茶樹害虫目録（茶業中 央会議所発行), pp. 47 (1943).

9) 南川仁博: 防虫科学, 22(1)，149～154（1957）.

\section{Summary}

The species of insects and tea insect pests caught by a light trap were surveyed from 1947 to 1979 by using a blueness fluorescent light trap set on the tea field of our research institute. The results obtained are as follows: 
1) From the results obtained from 1951 to 1960 survey, the number of caught insects was counted about one hundred thousand in a year in average, however, about $80 \%$ of these insects belonged to the order of lepidoptera.

2) 186 species of insects were confirmed among the caught insects, but the number of these insects were nothing but the one half of total number of caught insects.

3) 31 species of tea insect pests trapped by the surveys during 1947 to 1979. There names are as follows; that is, Holochlora japonica, Plautia stali, Lygocoris spinorai, Empoasca onukii, Geisha distinctissima, Spilosoma imparilis, Agrotis segetum, Spodoptera litura, Euproctis pseudoconspersa, E. subflava, Jankowskia athleta, Peristygis charon, Ascotis selenaria, Biston robustum, Megabiston plumosaria, Odontopera arida, Microleon longipalpis, Monema flavescens, Phrixolepia sericea, Zeuzera leuconotum, Clania formosicola, C. miuuscula, Herculia pelasgaris, Stemmatophora valida, Tamraca torridalis, Cerace xanthocosma, Adoxophyes sp., Homona magnanima, Caloptilia theivora, Heptophylla picea and Anomala rufocuprea.

(June 7, 1985) 